Boise State University

ScholarWorks

Anthropology Faculty Publications and

Presentations

Department of Anthropology

$12-2016$

\title{
Marital Dissolution and Child Educational Outcomes in San Borja, Bolivia
}

Kristin Snopkowski

Boise State University

This is an author-produced, peer-reviewed version of this article. The final, definitive version of this document can be found online at Human Nature published by Springer. The final publication is available at link.springer.com.

Copyright restrictions may apply. doi: 10.1007/s12110-016-9265-8 
This is an author-produced, peer-reviewed version of this article. The final, definitive version of this document can be found online at Human

Nature, published by Springer. Copyright restrictions may apply. doi: 10.1007/s12110-016-9265-8

\title{
Marital Dissolution and Child Educational Outcomes in San Borja, Bolivia
}

\author{
Kristin Snopkowski \\ Boise State University \\ Boise, Idaho \\ kristinsnopkowski@boisestate.edu
}

\begin{abstract}
Purpose: Serial monogamy is likely an adaptive mating strategy for women when the expected future fitness gains with a different partner are greater than expected future fitness with one's current partner.

Methods: Using interview data from over 400 women in San Borja, Bolivia, discrete-time event history analyses and random effects regression analyses are conducted to examine predictors of marital dissolution, separated by remarriage status, and child educational outcomes.

Results: Male income is inversely associated with women's risk of 'divorce and remarriage', while female income is positively associated with women's risk of 'divorce, but not remarriage'. Children of women who 'divorce and remarry' tend to have significantly lower educational outcomes than children of married parents, but women with higher incomes are able to buffer their children from the negative educational outcomes of divorce and remarriage. Counter to predictions, there is no evidence that women with kin in the community have a significant difference in likelihood of divorce or a buffering effect of child outcomes.

Conclusions: In conclusion, there are different predictors of divorce depending on whether the woman goes on to remarry, suggesting that male income may be a better predictor of a serial monogamy strategy, while female income predicts marital dissolution only. These results suggest that women who are relatively autonomous because of greater income may not benefit from remarriage.
\end{abstract}

Keywords: serial monogamy, divorce, remarriage, kin, Bolivia, education

\section{Introduction}

Serial monogamy is the practice of having multiple partnerships (or marriages) in sequence - where one relationship ends before the next relationship begins. From an evolutionary perspective, one would expect individuals who end an existing relationship to benefit from seeking out alternative relationships to increase their future reproductive success. Most evolutionary research on serial monogamy focuses on men's serial monogamy mating strategy as a means to achieve access to multiple females over their reproductive life, particularly in contexts where polygyny is prohibited (for example: Kaar et al. 1998; Marlowe 2000), but women may also use serial monogamy as a mating strategy, resulting in access to multiple males over their reproductive span (Borgerhoff Mulder 2009; Scelza 2013). Research generally finds that men who engage in serial monogamy increase their reproductive success, while women do not (Forsberg \& Tullberg 1995; Jokela et al. 2010; Kaar et al. 1998), but an exception exists among the Pimbwe, a population in western Tanzania; where women have greater reproductive success by engaging in serial monogamy than woman who marry once, but men who marry multiple times do not have greater reproductive success than males who only marry once (Borgerhoff Mulder 2009). It is likely that both men and women assess their own costs and benefits of serial monogamy and choose it as a mating strategy when it will improve their reproductive success. Extensive research has explored women's potential mixed strategy of pairing with a highly investing man and then, at peak-fertility, engaging in extra-pair copulations to attain genetic benefits (Baker \& Bellis 1995; Gangestad \& Thornhill 2008; Pillsworth \& Haselton 2006; but see Wood et al. 2014), a strategy of having both a short-term and a long-term mate at the same time. In contrast to this line of research, this paper will explore the conditions under which women engage in marital dissolution and subsequent remarriage and how these decisions influence child outcomes. 
This is an author-produced, peer-reviewed version of this article. The final, definitive version of this document can be found online at Human Nature, published by Springer. Copyright restrictions may apply. doi: 10.1007/s12110-016-9265-8

\section{Costs and Benefits of Serial Monogamy}

Marital dissolution (also referred to as divorce) is the first step in a serial monogamy mating strategy and is likely used as a strategy to maximize reproductive success (Choudhury 1995). There are costs and benefits in the decision to either stay with one's current partner or divorce in an attempt to re-partner with another mate. Broadly, remaining with one's current partner reduces time and energy costs of locating and attracting a new mate, and may allow for parents to maintain investments in joint children. However, staying with a current partner may also entail costs, particularly if that individual is violent or invests little in their mate and offspring. It is possible that being without a partner may actually improve overall fitness compared to being with a partner who endangers one's life or the life of offspring.

Marital dissolution also entails costs and benefits. The potential benefit of divorce includes the possibility of securing a higher-quality mate (either a mate with better genetic quality or a mate more willing and able to invest) or finding a mate with whom offspring viability improves. Divorce and remarriage is adaptive when the expected future fitness gain with a new mate is greater than the expected fitness gain with the current partner. If an individual chooses to divorce and not remarry, this can be adaptive if the expected gain in fitness with the current partner is actually worse than not having a partner at all (for example, if the partner's involvement actually reduces the quality of offspring or one's ability to invest in offspring in the future).

Given that humans are unique in having weaned offspring that remain dependent on parents for over a decade, costs of divorce may be particularly large for the parent who ends up caring for joint children, as that individual may have to provide more investment in offspring (if the other biological parent reduces investment in offspring due to the divorce) and it may hinder their ability to find another high-quality mate. Both parents may have reduced fitness if their joint offspring are less successful due to a reduction in parental investment from at least one parent because of divorce. Remarriage may also reduce fitness in offspring if the new mate is antagonistic towards children from a previous mate (Daly and Wilson 1985; Flinn 1988).

There are several hypotheses from the bird literature that explain when individuals are expected to pursue divorce as a means to maximize their fitness (Choudhury 1995; Dhondt 2002), and many of these are applicable to humans as well. First, the incompatibility hypothesis argues that couples with low breeding success are more likely to divorce (Coulson 1972; Choudhury 1995). In humans, this may occur in couples who either produce children with inherited genetic abnormalities or are unable to conceive offspring altogether. In this case, both individuals are expected to benefit from divorce by having higher expected fitness with other partners than with each other, and marital dissolution is likely to occur relatively early in their marriage.

The better option hypothesis states that an individual will decide to divorce their current partner if they can improve their reproductive success by mating with an alternative partner (Ens et al. 1993; Choudhury 1995). In this case, the partner who chooses to divorce may increase their reproductive success, but the partner who is deserted may be worse off - especially if they are unable to attract another mate or can only acquire a mate of lower-quality compared to their original mate. In humans, mate quality can vary dramatically across the lifespan. For example, women may have lower mate value as their reproductive function declines. Serial monogamy may be a strategy for individuals who possess higher mate quality than their partners.

It is also possible that individuals make errors in their original choice of partner, perhaps because they did not sample enough of the population to determine the best quality they could attain or that they inaccurately judged the mate value of their partner. After acknowledging the error in mate choice, the individual chooses to divorce their current partner. This hypothesis is known as the 'errors of mate choice hypothesis' (Johnston and Ryder 1987). In this case, divorce is expected relatively early in the marriage and should occur more often with younger individuals (who have had less time to sample the population), with one partner having higher expected fitness with an alternative partner.

It is usually difficult to determine who initiated divorce and it is even possible that those who have experienced divorce do not accurately perceive who the initiator was (for example, among the Ache foragers of eastern Paraguay, when asked who initiated a divorce, over $50 \%$ of men and over $50 \%$ of women claimed responsibility (Hill \& Hurtado, 1996)). Both men and women should be sensitive to the reproductive costs and benefits of marital dissolution. 
This is an author-produced, peer-reviewed version of this article. The final, definitive version of this document can be found online at Human Nature, published by Springer. Copyright restrictions may apply. doi: 10.1007/s12110-016-9265-8

Individuals who initiate divorce are expected to be able to improve their reproductive success, while the partner who was deserted may have reduced fitness due to the divorce. If the divorce was mutual, as in the case of the incompatibility hypothesis, both individuals should be able to improve their reproductive success with divorce.

\section{Child Outcomes}

Generally, one might expect children to fare worse if they lose investment from one of their parents. After divorce, it is likely that they no longer live with (at least) one parent, and even if the non-resident parent still invests, the amount of investment is likely reduced (Anderson et al. 1999). Further, children may not obtain the same level of investment with the introduction of a stepparent as they would with two biological parents, since the stepparent's fitness is not tied to the genetically unrelated stepchild (Flinn 1988). While stepparents commonly invest in stepchildren (investment commonly conceptualized as mating effort), it is hard to predict whether the introduction of a stepparent improves or worsens the outcomes of children. On one hand, introduction of a stepparent may increase overall investments to a child, which may improve the child's outcomes. On the other hand, if the relationship between a stepparent and stepchild is antagonistic or the new marriage results in additional children, the child may receive less investment than if the parent did not remarry, further worsening the child's outcomes.

If serial monogamy has a negative fitness effect on children, children of divorced parents should experience reduced survivorship or reduced reproductive success. In current low-mortality contexts, serial monogamy may not result in reduced survivorship (since mortality rates are extremely low), but instead may reduce investments that influence other aspects of the child's life, like educational achievement. Reducing investments in a child's education may result in the child having worse mate value at adulthood, reducing the child's chances of marrying, and may worsen their earning potential as an adult, hindering their ability to invest in their own children.

There is evidence from foraging populations, with relatively high infant and child mortality, that children tend to experience higher rates of mortality when their mothers divorce or remarry, although the direction of causality is not always certain (Pennington and Harpending 1988; Hurtado and Hill 1992; Winking et al. 2011, but see Blurton Jones et al. 2000) and evidence from a Dominican population shows that children who grow up with a stepparent may experience lower reproductive success as adults (Flinn 1988). In low-mortality, high-income contexts where much of the research on the effect of divorce on children's outcomes has been conducted, there is little child mortality - so most studies cannot detect an effect of divorce on child mortality rates, although introduction of a stepparent may increase the likelihood of mortality (Daly and Wilson 1988). Research from high-income countries has found evidence of worse educational outcomes for children with divorced parents (McLanahan et al. 2013). For example, evidence from the United States has found that children raised in single-mother families are less likely to complete secondary school (Astone \& McLanahan, 1991; Teachman et al., 1996) and have lower average occupational status (Biblarz and Gottainer 2000) than children raised in two-parent households.

\section{Divorce and Serial Monogamy}

Divorce is not the same as serial monogamy, but evolutionary theory predicts if divorce is an adaptive mating strategy and is chosen by a given individual, it is likely because the individual can acquire a higher-quality mate, resulting in serial monogamy. If an individual divorces and does not remarry, it is possible that a) the divorce was an adaptive choice by that individual because fitness improves by not being with their previous partner (possibly because that partner was abusive) or b) the individual is the victim of their previous partner's decision to divorce them. Now the deserted partner is either unable to attract another mate, or finding another mate may actually reduce fitness because of potential antagonistic interactions between stepparents and stepchildren. Finally, just because an individual remarries does not mean that they were the one to initiate the divorce. It is possible that finding a new partner enhances fitness more than staying single, but that being with their previous partner would have maximized their fitness. Throughout this paper, I distinguish between women who a) remained married, b) divorced and remarried and c) divorced and remain unmarried.

\section{Male versus Female Serial Monogamy}

While the previous discussion has not differentiated between the costs and benefits for males and females, this paper will focus specifically on females. There are several reasons for this: first, the benefits of serial monogamy for men are more obvious than they are for women, so an investigation into serial monogamy as a mating strategy for females 
This is an author-produced, peer-reviewed version of this article. The final, definitive version of this document can be found online at Human Nature, published by Springer. Copyright restrictions may apply. doi: 10.1007/s12110-016-9265-8

allows for a better examination of the costs and benefits of the strategy. Second, females in many contexts, including San Borja, Bolivia, where the data were collected for this study, are mainly responsible for childcare after a divorce. This means that the costs of serial monogamy are potentially much greater for females than males, so finding that females are still using serial monogamy as an adaptive strategy suggests that in some situations, the benefits of serial monogamy can outweigh the costs of raising children without the child(ren)'s father in the same household. Finally, it allows for an examination into how women may tradeoff help from male partners and kin.

\section{Predictions for Divorce and Remarriage}

If women are actively pursuing adaptive serial monogamy strategies, divorce should occur in particular situations. In an effort to improve fitness, women may choose divorce (and subsequently remarry) when they can obtain a betterquality mate. For humans, males can provide two kinds of benefits to females: genetic benefits and resources. Women need to trade off these potential benefits to maximize their fitness. If a woman is married to a man who is unable or unwilling to invest paternally, a woman may benefit by seeking out another partner who is more willing to invest. This may be linked to income, as men with fewer financial resources are less able to invest financially. It may also be associated with education, as men with greater levels of education tend to have greater income-generating power over the long term and may be better able to invest in the embodied capital of children (Kaplan 1996). This leads to the first hypothesis (H1): When males provide little investment, there will be an increased likelihood of divorce. Some empirical evidence from the United States and Finland shows that this may be the case as marital dissolution is reduced when males have higher incomes (Hoffman and Duncan 1995; South and Lloyd 1995; Jalovaara 2003) and marital dissolution increases when males are unemployed in Australia (Bracher et al. 1993).

With increasing access to the market-economy for women in modernizing economies, many women now have more access to wage labor and financial resources. Increasing access to the market-economy can influence divorce in many ways. First, it increases a woman's income, which may increase divorce rates through at least three routes: 1) a woman may have greater power to leave a non-investing partner as she can support herself while searching for a better mate, 2) a man may be able to leave his wife knowing that she (and possibly children) will still be able to survive without his investment (which may result in greater divorce without remarriage for the wife) or 3) women working in the wage labor market may have more exposure to alternative mates, leading to the possibility that a woman is more likely to find a higher-quality mate than her current husband. This leads to the following hypotheses (H2): Women who engage in the labor market will have greater likelihood of divorce and remarriage, (H3): If the mechanism by which labor market involvement increases divorce rates is by the increase to women's income, greater income levels will increase divorce and remarriage rates.

Some empirical evidence supports these predictions. Divorce rates increase when women have higher earning power (particularly when she earns more than her husband) (Bracher et al. 1993; Jalovaara 2003; Rogers 2004; but see Hoffman and Duncan 1995; Rogers and DeBoer 2001), although this may be moderated by gender ideology (Sayer and Bianchi 2000). Data from Mexico show that governmental cash transfers to mothers increase separation rates (Bobonis 2011), which provides strong evidence of the direct effect of income in this context. Additionally, there is evidence that women's employment in the modern labor-market is correlated with increased marital dissolution in some high-income contexts (Greenstein 1990; Poortman and Kalmijn 2002).

Female education may also influence divorce rates, but the direction of the effect is difficult to determine. On the one hand, more education may increase the likelihood of labor market participation. At the same time, education may increase age at first marriage, allowing women more time to search for and find a compatible mate. Evidence from high-income countries tends to find that low levels of education reduces marital stability (Tzeng and Mare 1995; Lyngstad 2004). Finally, there may also be fitness benefits to having genetic diversity in offspring, which increases the possibility that some offspring survive in a fluctuating environment (Jennions and Petrie 2000), but modeling work suggests that this benefit only exists under a narrow set of assumptions (Yasui 2001).

In many societies, women tend to be the main caregiver of children after union dissolution. If a woman has custody of children after divorce, a particularly high cost may be the disinvestment by her partner in joint offspring (Anderson et al. 1999). When other individuals, like kin, help women care for offspring, men may have a reduced cost of abandonment (Quinlan and Quinlan 2007). Alternatively, a woman may have reduced cost of martial dissolution if the lost disinvestment by her spouse can be compensated by supportive kin who are willing to provide additional support. This leads to the following hypothesis (H4a): Women with supportive kin have decreased rates of marital 
This is an author-produced, peer-reviewed version of this article. The final, definitive version of this document can be found online at Human Nature, published by Springer. Copyright restrictions may apply. doi: 10.1007/s12110-016-9265-8

stability. It is also possible that the reverse is true; women with helpful kin may be able to remain married to noninvesting partners - eliminating the cost of divorce to children - because of the support they receive from kin. This leads to an alternative hypothesis (H4b): Women with supportive kin may have increased rates of marital stability.

Empirical evidence has shown that the availability of allomothers, represented by a greater amounts of nonmaternal care, is associated with increased divorce rates (Quinlan and Quinlan 2007) and matrilineal societies tend to be associated with greater marital instability (Gibbs 1964; Minturn et al. 1969; Takyi and Gyimah 2007), which may be partly explained by women who rely on kin and are therefore less dependent on male partners for investment. This provides women the freedom to switch partners if they are unhappy with their current relationship or allows men to desert their wives knowing that other people are around to supplement investment. In contrast, evidence from the matrilineal Khasi of northeast India has shown that kin, particularly mothers, may contribute to good marital choices and therefore reduce the likelihood of divorce (Leonetti et al. 2007). Kin availability has been shown to have effects on many aspects of reproductive success including child survivorship (Borgerhoff Mulder 2007; Sear and Mace 2008; Sear et al. 2002), age at marriage (Moya et al. n.d.; Moya and Sear 2014), and reproductive rates (Sear and Coall 2011; Snopkowski and Sear 2013) and likely plays a role in marital dissolution as well.

Both men and women may benefit from marriage dissolution and possible re-partnership with an alternative partner. For individual women, the benefits may outweigh the costs if a) the benefits are large - for instance, she is able to attain a new mate who is willing and able to invest significantly more in both herself and her offspring than her current partner or b) the costs are small - if she needs little investment from a male partner, either because she has the resources to raise children on her own or she has other helpers (like kin) who can help her raise children.

\section{The Effect of Divorce and Remarriage on Child Outcomes}

If marital dissolution reduces the likelihood that both parents invest in their children, resulting in worse child outcomes, one might expect that mothers resort to divorce only in extreme circumstances (when the benefits can outweigh the large cost to offspring), but it is also possible that the reduction in child outcomes is not experienced equally by all mothers. Some mothers may be able to buffer their children from the negative consequences of divorce. If the main route by which children achieve lower levels of education is through reduced household resources, children of mothers with greater financial resources should buffer their children from reduced educational outcomes compared to mothers with fewer financial resources. Alternatively, women with supportive kin may also be able to buffer their children from reduced household resources or direct investments that may be associated with divorce and remarriage, allowing their children to complete intended levels of education. This leads to the following hypotheses (H5): divorce will lead to reduced educational outcomes for children; (H6): women with greater financial resources are able to buffer their children from the negative effects of divorce more than women with fewer financial resources; and (H7): women with kin in the community are able to buffer their children from the negative effects of divorce.

\section{'Divorce with Remarriage’ Compared to 'Divorce Without Remarriage'}

While divorce may be the first step in a serial monogamy strategy, women who do not remarry and do not engage in serial monogamy may be different from those who do. One might expect different factors to influence the likelihood of divorce for women who then go on to remarry compared to those who divorce and remain unmarried. For instance, leaving a low-investing male partner may make the most sense when a woman can remarry a higher-investing partner, suggesting that male income may be related to the likelihood of divorce and remarriage. In contrast, a woman's own income may mean that she is more likely to be deserted by her partner if she can support herself (as there is a reduced cost of desertion by the husband). If this is the case, then female income may predict 'divorce without remarriage' more than 'divorce with remarriage'. If, in contrast, women with greater income can use that income to facilitate partner switching, then I expect woman's income to predict 'divorce with remarriage' more than 'divorce without remarriage'. Throughout this paper, I will refer to 'divorce without remarriage' and 'divorce with remarriage' to differentiate between these two groups of women. 
This is an author-produced, peer-reviewed version of this article. The final, definitive version of this document can be found online at Human

Nature, published by Springer. Copyright restrictions may apply. doi: 10.1007/s12110-016-9265-8

\section{Methods}

\section{$\underline{\text { San Borja, Bolivia }}$}

To explore the hypotheses listed above, I will use data from women living in San Borja, Bolivia. This is an ideal place to explore how individual-level characteristics influence divorce rates because there are few structural constraints on divorce and people are free to choose their own partners (parents do not arrange marriages, which may improve couple compatibility). The majority of people in San Borja do not engage in a formal marriage, instead choosing cohabitation, which is generally referred to as 'marriage'. This makes dissolution of marriage particular easy for either individual to initiate and allows for these individual-level hypotheses about divorce and remarriage to be easily tested.

Data were collected in 2008 by interviewing approximately 400 women in San Borja, Bolivia. San Borja (SB) is located in the Bolivian Amazon, has a population of approximately 20,000 people, and is approximately $50 \mathrm{~km}$ to the next nearest town. The women sampled are ethnically Camba, an ethnic category of people originating from lowland Bolivia. There is another ethnic group in this community who originate from highland Bolivia who are excluded from this study because they tend to be immigrants to the community and generally have no kin network available. San Borja is predominantly a Catholic community, with cattle ranching as the main industry. The community is rapidly modernizing, with new technologies and new opportunities for employment. Approximately one third of women reported working outside the home, in professions such as a shopkeeper, secretary or teacher. For men, even though rates of education have been increasing, only about $7 \%$ of men were reported to work in occupations that require education (such as pharmacists, doctors, lawyers, or accountants). Many men have occupations that require little formal schooling, like taxi driving (13\%) or construction work (13\%).

Rates of education have been increasing, with women over 60 reporting only 3 years of education on average, but women under 30 reporting an average of 9.7 years. Education, particularly a secondary school diploma, is important for several employment opportunities in town. For example, both teaching and secretarial work require secondary school completion. The nearest university is located in Trinidad, approximately $200 \mathrm{~km}$ from San Borja, but there is an institute locally, where people can gain additional skills in a setting similar to a junior college. Many women reported that they obtained their current employment, in occupations such as administration, hairdressing, and banking, because of skills they learned at the institute. A few women reported that they had obtained university degrees and were using them in occupations such as pharmacy and nursing. For children who decide to emigrate from San Borja, having an education can improve their employment opportunities elsewhere as well. Some women surveyed reported that their children received university degrees and are currently employed in engineering, architecture, business, and medicine.

\section{Sampling}

A random sample of houses was generated in the community and at each selected house one woman was interviewed (women were selected randomly at first and then based on age to meet sampling goals). A stratified sample of ages was collected with one third of women under the age of 30, one third between 30 and 44 and the remaining third over the age of 45. Interviews were conducted in Spanish (the subjects' native language) to gather information on reproductive, marriage and employment histories, parental investment, and children's educational outcomes. Men were not interviewed, so their mating strategies cannot be examined. Further, women were asked about their children's educational outcomes, which they only answered if they were the child's caregiver. When children remained with their fathers after divorce (approximately 5\% of children), mothers tended not to know their level of educational achievement. Remarriage information was only collected for the interviewed woman - so details about her previous husband's remarriage experience is unknown. For additional details about the site and sampling, see Snopkowski \& Kaplan (2014).

\section{$\underline{\text { Variables }}$}

Women reported each of their 'marriages' including the year it began and the year it ended. Many individuals in San Borja consider themselves married even though no formal ceremony has taken place. For each marriage reported, women identified whether they were married by the church (5\%), by the state (20\%), both (married by both the church and state; $11 \%$ ) or had no formal ceremony (64\%). Many relationships in San Borja do not involve an official marriage ceremony, but people still refer to their partner as a spouse and act as married couples. In this paper, I will refer to 
This is an author-produced, peer-reviewed version of this article. The final, definitive version of this document can be found online at Human Nature, published by Springer. Copyright restrictions may apply. doi: 10.1007/s12110-016-9265-8

marriage, divorce, and remarriage even though many couples do not engage in official ceremonies to represent these events. A long-term union with another individual is considered a 'marriage' in this study, union dissolution is labeled 'divorce', and the start of a new union is referred to as 'remarriage'.

\section{Models for Divorce and Remarriage}

The first hypothesis is that male investment will influence divorce rates. Male investment is measured by a) the woman's report of whether her husband helped her with household bills (categorized as: never/rarely, sometimes, or always), b) the husband's income (reported in each year) and c) the husband's completed education (measured in years). Income was measured in bolivianos per month and natural log transformed to reduce skew.

The second set of hypotheses (H2-H3) is that female access to the labor market will increase the likelihood of divorce and remarriage. Female access to the labor market was measured by whether the woman worked outside the home (this variable is lagged by one year, so that whether the woman worked in the year before divorce is used). To test H3, that financial resources are the main mechanism by which labor market participation influences divorce rates, women reported income for each year (this variable is lagged by one year, so that the woman's income in the year before divorce is used). Women reported on all of their income-generating employment throughout their lives (all measured in bolivianos), the years they were engaged in each one, and the starting and ending income of these activities. For activities that were conducted over multiple years and the starting and ending salaries were different, a linear extrapolation was calculated to estimate income for each year. As with husband's income, woman's income is natural log transformed.

The fourth hypothesis proposes that women with kin networks in their community will have different rates of divorce. Whether women have kin networks in their community was measured by a) whether the woman lived in San Borja by the time she was 15 (suggesting she grew up there; this was also analyzed strictly for women who were born in San Borja, but this did not change the results) and b) whether the woman had any siblings in San Borja. While parental presence may be a better measure of kin support, this information was not collected from subjects, so kin support is proxied by whether the woman grew up in the community or if her siblings live in San Borja. While availability of siblings may indicate kin support, as siblings may help each other with childcare, help each other's children locate employment opportunities, and help in time of financial need, they may also indicate competition, as siblings may have their own offspring or financial woes and not be in a position to provide support.

I conducted a discrete-time event history analysis for each marriage to determine the likelihood of divorce. Event history analyses model the time until an event occurs and are able to accommodate censored and time-dependent variables. Time was measured as the duration of each marriage in years (time equals zero at the start of marriage). I conducted a random effects model to group marriages by woman, as some women had multiple marriages and each marriage is not independent if a given woman is at an increased risk of divorce across multiple marriages. To distinguish between women who 'divorced and remarried' and those who 'divorced without remarriage', separate discrete-time event history analyses were run for: a) all divorces, b) divorces that resulted in remarriage and c) divorces that did not result in remarriage.

To account for the curvilinear effect of divorce after marriage, years since the marriage began and its square term are included. Divorce is much more likely to occur within the first five years of marriage and then the rate of divorce decreases with time. Women's education, measured in years, was also included, but the predicted direction of the effect is difficult to determine (see 'Predictions for Divorce and Remarriage' section above). Other variables included in the models are: birth cohort of the woman, to control for secular trends in divorce rates; type of marriage, as an official marriage ceremony tends to reduce the rate of divorce; frequency of church attendance, to control for the possibility that religiosity influences the likelihood of divorce; and the number of joint children of the couple, as couples may be less likely to divorce once they have many children who experience the negative effects of that divorce.

\section{Models for Child Outcomes}

In low-mortality contexts, divorce and remarriage are unlikely to have significant effects on child mortality. In San Borja, of the 112 children (under age 18) who died, 73\% (or 82) of them died before their first birthday, suggesting that most child mortality occurs within the first year of life. Of the children that died, $75 \%$ had parents who remained married until the time of interview, $22 \%$ had parents who divorced after their death, $2 \%$ had parents who divorced in 
This is an author-produced, peer-reviewed version of this article. The final, definitive version of this document can be found online at Human Nature, published by Springer. Copyright restrictions may apply. doi: 10.1007/s12110-016-9265-8

the same year of death (although these two children died before their first birthday) and $<1 \%$ (only 1 individual) died after the divorce of her parents. Given the very low rate of child mortality after divorce, there is no evidence that divorce influences child mortality in this context.

Since divorce and remarriage do not affect child mortality in San Borja, I instead focus on child's completed education as the outcome of interest. Education is measured in years and ranges from 0 to 16 . Children were only included if they no longer attend school. Unfortunately, it is impossible to know how much education children will attain in the future if they are still currently enrolled in school (and their current educational achievement is highly linked to their age). For this set of predictions, I compare children whose parents a) remain married, b) divorced and their mothers have not remarried (known as 'divorce without remarriage') and c) divorced and their mothers have remarried (known as 'divorce with remarriage').

For analyses of children's educational outcomes, regression analyses were conducted where each child was the unit of analysis. A random effect was included to control for children of the same mother. Children were only included in the analyses if they were no longer attending school and their parents either did not divorce or divorced by age 15 (since divorce after that age may have occurred after they had already left school). These analyses control for: mother's and father's education, as education of parents is highly correlated with child's education; child's age, to control for increasing educational achievement through time; birth order, as first-born children tend to have higher educational outcomes than later-born children; number of siblings, as more siblings may reduce investment from parents; and sex of the child.

Many of the variables had some missing values. To minimize potential biases related to values that may be missing non-randomly, all analyses (including models for divorce/remarriage and child outcomes) were run using multiple imputation. Ten imputed datasets were calculated using the ICE method in STATA v. 13 (Royston 2005).

\section{Results}

Descriptive statistics of both independent and dependent variables can be found in Table 1. Of the 526 marriages reported, one-third of them ended in divorce and another $4 \%$ ended in widowhood. The remaining $63 \%$ of marriages were ongoing at time of interview. Of the 394 women who had ever married, $75 \%$ of women had only been married once, with $21 \%$ marrying twice and $4 \%$ marrying three or more times. Of marriages that end, 35\% end within the first two years and an additional 30\% within the next three years. After divorce, approximately 50\% of women report getting remarried within four years. By 10 years, approximately $65 \%$ of women have remarried, but after this period of time, remarriage is unlikely to occur.

\section{Factors Influencing Divorce and Remarriage}

\section{Male Investment}

Table 2 presents the results of the random effects discrete-time event history analysis predicting progression to a) any divorce, b) divorce for women who remarried and c) divorce for women who have not remarried. These groupings allow for differentiation between women who may be following a serial monogamy strategy of divorce and remarriage from those who experience marital dissolution and remain single. As predicted, higher male incomes reduce the likelihood of 'any divorce'. When the models are separated by remarriage status, lower male incomes are significantly associated with 'divorce and remarriage', while there is no significant effect for 'divorce without remarriage'. This is as expected; women who have low investing partners (measured by male income) may choose to switch to a partner who can invest more; leading to 'divorce with remarriage', but not 'divorce without remarriage'.

Another measure of husband's investment is whether the husband helped with household bills (as reported by the wife). This is also a significant predictor of divorce, where men who help with bills are significantly less likely to experience marital dissolution - and this holds for both 'divorce with remarriage' and 'divorce without remarriage'. A third potential measure of husband's investment is his education, with the expectation that men with more education may have greater income-generating power over the long term and may be better able to invest in the embodied capital of children. Counter to predictions, husband's education has no significant effect on likelihood of divorce, 'divorce with remarriage', or 'divorce without remarriage'. 
This is an author-produced, peer-reviewed version of this article. The final, definitive version of this document can be found online at Human Nature, published by Springer. Copyright restrictions may apply. doi: 10.1007/s12110-016-9265-8

\section{Female Labor Market}

The next set of hypotheses predicts that women who engage in the labor market will have a greater likelihood of divorce, possibly because of greater income levels or exposure to alternative mates. According to Table 2, women with higher incomes have a greater likelihood of 'any divorce'. When the models are separated by remarriage status, women with higher incomes are more likely to 'divorce without remarriage', but not to 'divorce with remarriage'. This is not surprising because women with greater incomes are able to support themselves, suggesting that they may be less likely to remarry or their partners may be more likely to desert them, resulting in 'divorce without remarriage', but not 'divorce with remarriage'.

Examining employment status before divorce, women who work outside the home are not more likely to divorce regardless of remarriage status. This may be because the main route by which female employment influences divorce is through women's income, which is already included in the model. Re-analyzing the models without women's income shows that working outside the home (compared to not working) significantly increases the likelihood of engaging in 'divorce without remarriage', but not 'divorce with remarriage' (model not shown). This provides evidence that income mediates the relationship between female employment and divorce (particularly 'divorce without remarriage').

\section{Family}

Hypothesis 4 states that women with supportive kin will have different rates of divorce compared to those without kin (hypothesis 4a claims a reduction in marital stability, while hypothesis 4b argues for an increase in martial stability). In contrast to the hypothesis, there is no evidence that women who lived in San Borja from an early age have a different likelihood of divorce - regardless of remarriage status. An alternative measure of 'kin availability' is whether the woman has siblings living in the community. Again, this variable has no effect on divorce rates, counter to the hypothesis.

\section{Other Covariates}

Several other covariates were also included in the model, including years married and its square term, to control for marriage duration. The model shows that with greater marital duration, divorce rates decline at a decreasing rate. Type of marriage (religious marriage, civil marriage, both or neither) is also included and results demonstrate that having both types of marriage ceremonies leads to a reduction in the likelihood of divorce. This may be related to religiosity (where more religious individuals are less likely to divorce due to church teachings), although there is no evidence of a significant correlation between likelihood of divorce and religiosity. Using a religiosity measure, I find no effect of self-reported ‘importance of religion’ (not shown), and therefore excluded it from the model, but frequency of church attendance does have a significant effect, where people with weekly church attendance are less likely to engage in 'divorce with remarriage'. Interestingly, this is not the case for people who attend church multiple times per week, but suggests that level of religiosity might be better measured by frequency of church attendance, instead of self-reported level of importance. Women's education increases the likelihood of divorce (even after controlling for income) for 'any divorce'. When this is separated by women's remarriage status, women with more education are more likely to 'divorce without remarriage', while there is no significant effect on 'divorce with remarriage'. Birth cohort of the woman was included to control for secular trends in divorce, but it had no effect on the 'any divorce' model. When this was split into 'divorce with remarriage' and 'divorce without remarriage', the evidence shows that compared to the reference category of women born since 1980, women in previous cohorts are more likely to 'divorce and remarry' and are less likely to 'divorce without remarriage'. It is possible that women who have divorced in the recent cohort (1980-present) will remarry in the future and therefore the effect represents a censoring problem. It is also possible that previous cohorts were more likely to engage in serial monogamy, while the most recent cohort is more likely to divorce and remain single. The number of joint children that a couple had was also included in the model and shows that couples with more children are more likely to engage in divorce, particularly 'divorce with remarriage'. This is counter to expectations since the more offspring a couple has, the greater the potential cost to children in engaging in divorce or remarriage, but may occur because most couples progress to first birth quite rapidly (or pregnancy actually instigates the marriage). A model including an interaction between wife's and husband's income was also tested, but was not significant. 
This is an author-produced, peer-reviewed version of this article. The final, definitive version of this document can be found online at Human Nature, published by Springer. Copyright restrictions may apply. doi: 10.1007/s12110-016-9265-8

\section{$\underline{\text { Child Outcomes }}$}

\section{Divorce and Remarriage Effects on Child Outcomes}

Figure 1 presents the predicted educational achievement of children depending on parent's marital status; comparing a) 'divorced but not remarried' mothers, b) 'divorced and remarried' mothers, and c) married parents (model not shown). Children whose mothers who have engaged in serial monogamy (divorce with remarriage) have significantly lower educational outcomes, approximately 1.2 years on average, compared to children with married parents.

The model controls for likely covariates, such as mother's and father's education, which both have a significant positive effect on child's educational outcome; child's age to control for increasing levels of education through time, although this variable is not a significant predictor of educational outcome (this may be because the secular change in education is accounted for by mother's and father's education); birth order, as first-born children have higher educational achievement than later-born children in this context; child's sex, to control for sex-biased investment, although this variable is not significant; and finally, child's number of sibling, where more siblings shows a reduction in educational achievement.

\section{Are women with greater financial resources able to buffer their children from the negative effects of divorce and remarriage?}

Figure 2 presents the predicted educational achievement for children based on the interaction between mother's income in the year prior to divorce and parent's marital status, with the expectation that women with greater financial resources will be able to buffer their children from the negative consequences of divorce and remarriage (for full model, see Table 3). Children of women who did not work before 'divorce and remarriage' or who earned in the bottom 50\% of income, have lower educational outcomes than children whose parents remained married. As predicted, children of women who earned in the top $50 \%$ of income before 'divorce with remarriage' did not have a significant decline in educational achievement, although the predicted value is somewhat lower (about 0.8 years) than children whose parents remained married. When comparing the educational outcomes for children of mothers who 'divorced without remarriage' to children whose parents remain married, there is no significant difference in educational outcomes. For children of mothers who did not work before divorce and did not remarry, their educational outcomes are actually even higher (although not significantly) than parents who remain married. It should be noted that this group of women is very small, and only represents 6 children coming from 3 separate mothers (as can be seen by the large standard errors).

Other covariates include mother's and father's education, child's year of birth, birth order, sex, and number of siblings and each have similar effects to those described in the previous section (for the full model, see Table 3).

\section{Are women with kin in the community able to buffer their children from the negative effects of divorce and remarriage?}

Figure 3 presents the predicted educational outcomes for children based on whether their mothers have siblings in the community and whether their mothers lived in San Borja by the age of 15 (listed in the figure as 'sibs SB' and 'from SB', respectively) by parent's marital status (for full model, see Table 4). There were no women in the category 'never remarried, lived in SB before age 15, no siblings in SB', so this category was removed. The one category that significantly reduces children's educational outcomes compared to children from the 'parents married' categories is children of women who have remarried, lived in SB before age 15 and have siblings in SB; the educational achievement of these children is approximately 1.6 years less than those with 'married parents'. Similarly, children of women who have remarried, did not live in SB before 15, but have siblings in SB have comparable educational outcomes to the 'remarried, not from SB, no sibs SB' category, but since there are fewer women in this category, the standard error is larger resulting in a non-significant difference with the 'married parents' categories. This suggests that, counter to predictions, having kin available actually worsens children's outcomes when women divorce and remarry. 
This is an author-produced, peer-reviewed version of this article. The final, definitive version of this document can be found online at Human Nature, published by Springer. Copyright restrictions may apply. doi: 10.1007/s12110-016-9265-8

\section{Discussion}

Results indicate that a) when husbands contribute little to the household, women are more likely to 'divorce and remarry' other men, b) when women contribute more to the household (in terms of income), women are more likely to 'divorce without remarriage', c) children of women who 'divorce and remarry' tend to have reduced educational outcomes, but d) children of women who 'divorce and remarry' and earn in the top $50 \%$ of income immediately before divorce are somewhat buffered from these negative educational outcomes, and e) there is no evidence that having kin available in the community influences divorce rates or buffers children from negative educational effects of 'divorce and remarriage' (for a summary of results by hypothesis, see Table 5).

One of the strengths of these analyses is the ability to separate out divorced women who either remarried or remained single. While I have no information on who initiates divorce and it is hard to know if people within a given couple would be able to identify the original motivator if asked, the different results for the 'divorced with remarriage' and 'divorced without remarriage' groups are telling. Males who contribute little to the household are more likely to have wives who experience 'divorce with remarriage', but not 'divorce without remarriage'. This suggests that these women are able to attract different partners, presumably ones who are able to invest more. In contrast, women who have greater incomes are more likely to 'divorce without remarriage', but not 'divorce with remarriage'. These women are more likely to end up without a partner, but it is hard to determine who is initiating divorce. It is possible that women with very little income prior to divorce are more motivated to find a new partner after divorce. Contrary to the original hypothesis that women who engage in the labor market would be more likely to engage in 'divorce and remarriage', the evidence suggests that women who engage in the labor market are more likely to 'divorce, but not remarry' and that this relationship is mediated by the income that women earn. There is no added effect of labor market participation on divorce above that from women's income, suggesting that exposure to alternative mates in the labor market is not driving divorce.

Hypothesis 1 states that when males provide little investment, there will be an increased likelihood of divorce and remarriage, but I have only analyzed the effect of husband's income and reported help with household bills - both measures of financial investment - and husband's education, which had no significant effect. Data were not collected on men's direct investments in children, so it is not known if divorce rates decline with increasing direct care as well. Direct paternal care may be an important determinant of divorce in contexts where women can provide financial resources for her family (in contrast, if women are excluded from the labor market, male financial investment is likely more important than direct paternal care). Future work should explore the influence of direct paternal care for families where women are involved in the labor market in contexts like San Borja. Some evidence suggests that among American couples both engaged in the labor market, when women report an unfair division of household labor, there is an increased likelihood of divorce (Frisco and Williams 2003).

Some evidence has shown that with modernization, particularly when women have increased wage labor participation, the rate of divorce increases (see examples: Spitze and South 1985; Bracher et al. 1993), although it is also possible for divorce rates to decline with modernization in some contexts, possibly due to the reduction in arranged marriages (Jones 1994). As women become more highly educated and spend more time in the wage labor market in San Borja, one may expect the levels of divorce to increase - although this study suggests that the mechanism by which wagelabor participation influences divorce is through the increased income of women.

Contrary to predictions, I found that living in San Borja prior to adulthood or having siblings living in San Borja does not influence the rate of divorce. The measure - living in San Borja prior to adulthood - was used as a proxy for kin availability. I expected that having kin around may influence rates of divorce as there could be a tradeoff between husband's and kin's investments. For women with more access to kin, they may be less reliant on husband's investments. This may either increase divorce rates as women are less dependent on men to stay in a marriage or it could decrease divorce rates because women can garner investments from kin and remain with men who provide little investments so as to reduce the potential negative effects of divorce on children. Given that previous research has found that greater allomaternal care increases divorce rates (Quinlan and Quinlan 2007) and matrilineal societies tend to have higher levels of marital instability (Gibbs 1964; Minturn et al. 1969; Takyi and Gyimah 2007), one might expect women with kin in the community to have higher divorce rates, but this is not what I find in San Borja; a community that is primarily neolocal. Given that these previous studies look at the effect of kin on group-level divorce rates, while this study examines the effect of kin on individual-level divorce rates, there may be distinct factors accounting for divorce rates at the different levels of analysis. 
This is an author-produced, peer-reviewed version of this article. The final, definitive version of this document can be found online at Human Nature, published by Springer. Copyright restrictions may apply. doi: 10.1007/s12110-016-9265-8

The evidence suggests that children of mothers who 'divorced and remarried' had lower educational outcomes than children of parents who remained married. Interestingly, this was not the case for children of mothers who 'divorced without remarriage', where these children tended to have similar educational outcomes to children whose parents remained married. While I originally expected divorce to have negative outcomes on children's educational achievement because of reduced investments by at least one parent after divorce, this effect is actually strongest for the children of women who 'divorce and remarry', who may actually have additional resources/investments from their new stepfather. This suggests that the reduction in household income is not the driving factor in reduced educational outcomes. Why would the introduction of a stepfather lead to a reduction in educational outcomes? It is possible that there is an antagonistic relationship between the stepfather and stepchildren (Daly and Wilson 1988; Flinn 1988), which leads to reduced educational achievement or that this new marriage results in additional children, further reducing the investments given to children from the prior relationship compared to investments received if the mother remained unmarried. There is evidence that this is not an unusual trend, as researchers have documented the negative impact of stepfather presence on educational achievement in the United States (Biblarz and Raftery 1999; Keith and Finlay 1988, but see Beller and Chung 1992), possibly due to stepfather conflict with stepchildren over the mother's resources (Biblarz and Raftery 1999).

The children of women who earn in the top $50 \%$ of income before divorce appear to be somewhat buffered from the negative educational outcomes associated with 'divorce and remarriage'. Given that it does not appear that reduced household resources is the driving factor in reduced educational outcomes (as children of women who 'divorced without remarriage' do not have reduced educational outcomes compared to children of 'married parents'), how can one explain this result? It is possible that women who earn more income before divorce have more power in the new marriage to buffer previous children from potential conflict with a new stepfather or have greater 'mate value' to select a new partner who will have more positive interactions with stepchildren.

Counter to predictions, there was no evidence that having kin in the community buffered children from the reduced educational achievement associated with divorce and remarriage and if anything, children whose mothers 'divorced and remarried' and had siblings in the community had significantly reduced educational outcomes compared to children whose parents remained married, while all other categories of children were not significantly different from the 'parents married' category (see Figure 3). Having kin in the community may actually reduce the need for educational attainment as employment may be derived from kin or social networks over educational achievements. For individuals without kin in the community, educational achievement may actually be more important since they have smaller networks to help locate employment - particularly after divorce, where children may have less access to their father's social network. But the evidence collected on how people obtain employment does not support this hypothesis, as women are equally likely to gain employment from social connections if they are from San Borja (or having siblings in the community) or not.

There are several limitations to this study. First, there may be recall bias in the measure of income in each year which may be worse for years further in the past. To test whether this bias may be driving the results, I re-ran the divorce models ( 3 models: all divorces, divorced and remarried, divorced without remarriage) only using years since 2000 for all divorces and years since 1990 for the models separated by remarriage status (so that the models had enough data to converge) and the effects of income (both husband's and woman's) remain the same as described above. This suggests that while there may be inaccuracies in the recall of income, the effects remain consistent if I only use the most recent income data reported.

Second, reverse causation could also be a problem - as a woman prepares to leave a partner she may begin earning more income, instead of having a divorce as a result of increased earnings. The same may be true for husband's income, where a husband chooses to earn less or leads his wife to believe he earns less if divorce is imminent. This may be particularly problematic with women's report of husband's payment of household bills. I found that when women report that their husbands help less with household bills, there is an increased risk of divorce. Again, the direction of causality is difficult to know for certain, as the soured relationship may be biasing perceptions of previous male investment as opposed to his lack of help for household necessities resulting in divorce. Finally, it is also possible that in couples where women provide instrumental support to their husbands, men have increased income because of that support, and the supportive relationship makes the couple less likely to divorce. 
This is an author-produced, peer-reviewed version of this article. The final, definitive version of this document can be found online at Human Nature, published by Springer. Copyright restrictions may apply. doi: 10.1007/s12110-016-9265-8

While this paper examines divorce and remarriage as a potential serial monogamy mating strategy for women, with the expectation that women will engage in this strategy when future fitness gains with an alternative partner are greater than those with one's current partner, I have not actually compared the fitness of these two choices, since it is impossible to know a woman's fitness for a decision that she did not make. The evidence does suggest that women who have three marital partners have significantly more children (who survived to at least one year) than woman who had only one spouse (analysis not shown). Also, on average, women who remarry have 2.9 additional children after their first marriage. Only $12 \%$ of women who divorced and remarried did not go on to have additional children (by the time of the interview). This suggests that remarriage may lead to improved fitness, although it is impossible to know a woman's fitness if she had stayed with her original partner.

The outcome I analyzed for children's success, educational achievement, is not a fitness outcome. Educational achievement might actually reduce one's fitness if education is associated with reduced fertility rates as has been shown for women in this context (Snopkowski and Kaplan 2014). While education may not improve fitness, it does have a positive effect on a child's adult income. Income and education are significantly positively correlated for both men and women in San Borja (although the effect is larger for men than women). Men who go from 8 to 12 years of education can expect to earn approximately 324 more bolivianos/month. For parents who invest in children's education, those children likely have increased income to invest in their own offspring. An examination of child survivorship provides no evidence that divorce or remarriage has negative impacts on child survival. This casts some doubt as to the true fitness cost to children of parental divorce and remarriage in this context, although other studies conducted in the same region among the Tsimane, a forager-horticultural population living in the area around San Borja, have also had difficulty detecting significant effects of divorce or father death on child outcomes (Winking et al. 2011b; Winking et al. 2011a).

In conclusion, I provide evidence that there are different factors influencing the likelihood of 'divorce with remarriage' and 'divorce without remarriage' in San Borja, Bolivia. Husband's income is inversely related to the likelihood of a woman engaging in a serial monogamy strategy - divorce with remarriage - while wife's income is positively correlated with 'divorce without remarriage'. The serial monogamy strategy may provide benefits to women who are a) able to attract mates who are more willing and able to invest and b) go on to have additional offspring, but one might expect their children from the original marriage to experience reduced investments and possibly have worse child outcomes. There is no evidence that children are experiencing higher child mortality after their parents' divorce (or remarry), but children whose mothers 'divorce and remarry' have reduced educational outcomes compared to children whose parents remain married and children whose mothers divorced but did not remarry. This suggests that there may be costs to a serial monogamy strategy for women and that they have to weigh these costs and benefits of marital strategies to optimize the fitness of their current and future offspring.

\section{Acknowledgements}

I would like to thank the women of San Borja, Bolivia who participated in this study, the research assistants that helped collect data, and Hilly Kaplan for logistical support in the field. Thank you to Susie Schaffnit, Paula Sheppard, Siobhán Mattison, Rebecca Sear, Monique Borgerhoff Mulder, and two anonymous reviewers for helpful feedback. This research was funded by the University of New Mexico Graduate and Professional Student Association and the University of New Mexico Office of Graduate Studies. All participants provided their informed consent prior to interview and this research was conducted under the University of New Mexico IRB protocol \#27186. 
This is an author-produced, peer-reviewed version of this article. The final, definitive version of this document can be found online at Human Nature, published by Springer. Copyright restrictions may apply. doi: 10.1007/s12110-016-9265-8

\section{References}

Anderson KG, Kaplan H, Lancaster J (1999) Paternal Care by Genetic Fathers and Stepfathers I: Reports from Albuquerque Men. Evol Hum Behav 431:405-431.

Astone NM, McLanahan SS (1991) Family Structure, Parental Practices and High School Completion. Am Sociol Rev 56:309-320.

Baker R, Bellis M (1995) Human Sperm Competition: Copulation, Masturbation, and Infidelity. Chapman \& Hall, London

Beller AH, Chung SS (1992) Population Economics achievements. J Popul Econ 5:39-59.

Biblarz TJ, Gottainer G (2000) Family Structure and Children's Success: A Comparison of Widowed and Divorced Single-Mother Families. J Marriage Fam 62:533-548.

Biblarz TJ, Raftery AE (1999) Family Structure, Educational Attainment, and Socioeconomic Success: Rethinking the "Pathology of Matriarchy." Am J Sociol 105:321-365.

Blurton Jones NG, Marlowe F, Hawkes K, O’Connell JF (2000) Paternal investment and hunter-gatherer divorce rates. In: Chagnon N, Cronk L, Irons W (eds) Adaptation and Human Behavior: An Anthropological Perspective. Aldine de Gruyter, New York, pp 69-90

Bobonis GJ (2011) The impact of conditional cash transfers on marriage and divorce. Econ Dev Cult Change 59:281-312. doi: 10.1086/657123

Borgerhoff Mulder M (2009) Serial Monogamy as Polygyny or Polyandry? Hum Nat 20:130-150. doi: 10.1007/s12110-009-9060-x

Borgerhoff Mulder M (2007) Hamilton's rule and kin competition: the Kipsigis case. Evol Hum Behav 28:299-312. doi: 10.1016/j.evolhumbehav.2007.05.009

Bracher M, Santow G, Morgan SP, Trussell J (1993) Marriage Dissolution in Australia: Models and Explanations. Popul Stud (NY) 47:403-425. doi: 10.1080/0032472031000147216

Choudhury S (1995) Divorce in birds: a review of the hypotheses. Anim Behav 50:413-429. doi: 10.1006/anbe.1995.0256

Coulson JC (1972) The significance of the pair-bond in the kittiwake. Proc Int Ornithol Congr 15:424-433.

Daly M, Wilson M (1985) Child abuse and other risks of not living with both parents. Ethol Sociobiol 6:197-210.

Daly M, Wilson M (1988) Homicide. Aldine de Gruyter, New York

Dhondt AA (2002) Changing mates. Trends Ecol Evol 17:55-56. doi: 10.1016/S0169-5347(01)02407-7

Ens BJ, Safriel UN, Harris MP (1993) Divorce in the long-lived and monogamous oystercatcher, Haematopus ostralegus: incompatibility or choosing the better option? Anim Behav 45:1199-1217.

Flinn M V. (1988) Step- and genetic parent/offspring relationships in a Caribbean village. Ethol Sociobiol 9:335369.

Forsberg AJL, Tullberg BS (1995) The relationship between cumulative number of cohabiting partners and number of children for man and women in modern Sweden. Ethol Sociobiol 16:221-232.

Frisco ML, Williams K (2003) Perceived Housework Equity, Marital Happiness, and Divorce in Dual-Earner Households. J Fam Issues 24:51-73. doi: 10.1177/0192513X02238520

Gangestad SW, Thornhill R (2008) Human oestrus. Proc R Soc B Biol Sci 275:991-1000. doi: 10.1098/rspb.2007.1425

Gibbs JL (1964) Social Organization. In: Tax S (ed) Horizons of Anthropology. Aldine, Chicago, pp 160-170

Goode WJ (1993) World Changes in Divorce Patterns. New Haven and London

Greenstein TN (1990) Marital Disruption and the Employment of Married Women. J Marriage Fam 52:657-676.

Hill K, Hurtado AM (1996) Ache Life History. Aldine de Gruyter, Hawthorne, NY

Hoffman SD, Duncan GJ (1995) The Effect of Incomes, Wages, and AFDC Benefits on Marital Disruption. J Hum Resour 30:19-41. doi: 10.2307/146189

Hurtado AM, Hill K (1992) Paternal Effect on Offspring Survivorship among Ache and Hiwi Hunter-Gatherers: Implications for Modeling Pair-Bond Stability. In: Hewlett B (ed) Father-Child Relations: Cultural and Biosocial Contexts. Aldine de Gruyter, New York, pp 31-55

Jalovaara M (2003) The joint effects of marriage partners' socioeconomic positions on the risk of divorce. Demography 40:67-81. doi: 10.1353/dem.2003.0004

Jennions MD, Petrie M (2000) Why do females mate multiply? A review of the genetic benefits. Biol Rev Camb Philos Soc 75:21-64. doi: 10.1017/S0006323199005423

Johnston VH, Ryder JP (1987) Divorce in larids: a review. Colon Waterbirds 10:16-26.

Jokela M, Rotkirch A, Rickard IJ, et al (2010) Serial monogamy increases reproductive success in men but not in women. Behav Ecol 21:906-912. doi: 10.1093/beheco/arq078 
This is an author-produced, peer-reviewed version of this article. The final, definitive version of this document can be found online at Human Nature, published by Springer. Copyright restrictions may apply. doi: 10.1007/s12110-016-9265-8

Jones GW (1994) Marriage and Divorce in Islamic South-East Asia. Oxford University Press, Oxford

Jones GW (1997) Modernization and Divorce: Contrasting Trends in Islamic Southeast Asia and the West. Popul Dev Rev 23:95-114. doi: 10.2307/2137462

Kaar P, Jokela J, Merila J, et al (1998) Sexual Conflict and Remarriage in Preindustrial Human Populations: Causes and Fitness Consequences. Evol Hum Behav 19:139-151.

Kaplan H (1996) A Theory of Fertility and Parental Investment in Traditional and Modern Human Societies. Yearb Phys Anthropol 39:91-135.

Keith VM, Finlay B (1988) The Impact of Parental Divorce on Children 's Educational Attainment , Marital Timing , and Likelihood of Divorce. J Marriage Fam 50:797-809.

Leonetti DL, Nath DC, Hemam NS (2007) In-law Conflict: Women's Reproductive Lives and the Roles of their Mothers and Husbands among the Matrilineal Khasi. Curr Anthropol 48:861-890. doi: 10.1086/520976

Lyngstad TH (2004) The impact of parent's and spouses' education on divorce rates in Norway. Demogr Res 10:121-142. doi: 10.4054/DemRes.2004.10.5

Marlowe F (2000) Paternal investment and the human mating system. Behav Processes 51:45-61.

McLanahan SS, Tach L, Schneider D (2013) The causal Effects of Father Absence. Annu Rev Sociol 399:399-427. doi: 10.1016/j.biotechadv.2011.08.021.Secreted

Minturn L, Grosse M, Haider S (1969) Cultural Patterning of Sexual Beliefs and Behavior. Ethnology 8:301-318.

Moya C, Borgerhoff Mulder M, Colleran H, et al Intergenerational conflict may explain why parents delay the onset of their children's reproduction: A cross-cultural analysis.

Moya C, Sear R (2014) Intergenerational conflicts may help explain parental absence effects on reproductive timing: a model of age at first birth in humans. PeerJ 2:e512. doi: http://dx.doi.org/10.7287/peerj.preprints.345v1

Pennington R, Harpending H (1988) Fitness and fertility among Kalahari !Kung. Am J Phys Anthropol 77:303-319. Pillsworth E, Haselton M (2006) Women's sexual strategies: The evolution of long-term bonds and extrapair sex.

Poortman A-R, Kalmijn M (2002) Women's Labour Market Position and Divorce in the Netherlands: Evaluating Economic Interpretations of the Work Effect. Eur J Popul 18:175-202.

Quinlan RJ, Quinlan MB (2007) Evolutionary Ecology of Human Pair-Bonds: Cross-Cultural Tests of Alternative Hypotheses. Cross-Cultural Res 41:149-169.

Rogers SJ (2004) Dollars, Dependency, and Divorce: Four Perspectives on the Role of Wives' Income. J Marriage Fam 66:59. doi: 10.1111/j.1741-3737.2004.00005.x

Rogers SJ, DeBoer DD (2001) Changes in wives' income: Effects on marital happiness, psychological well-being, and the risk of divorce. J Marriage Fam 63:458-472. doi: 10.1111/j.1741-3737.2001.00458.x

Royston P (2005) Multiple imputation of missing values: update. Stata J 5:188-201.

Sayer LC, Bianchi SM (2000) Women's Economic Independence and the Probability of Divorce: A Review and Reexamination. J Fam Issues 21:906-943. doi: 0803973233

Scelza B (2013) Choosy but not chaste: multiple mating in human females. Evol Anthropol 22:259-69. doi: 10.1002/evan.21373

Sear R, Coall D (2011) How much does family matter? Cooperative breeding and the demographic transition. Popul Dev Rev 37:81-112.

Sear R, Mace R (2008) Who keeps children alive? A review of the effects of kin on child survival. Evol Hum Behav 29:1-18. doi: 10.1016/j.evolhumbehav.2007.10.001

Sear R, Steele F, Mcgregor IA, Mace R (2002) The Effects of Kin on Child Mortality in Rural Gambia. Demograhy 39:43-63.

Snopkowski K, Kaplan H (2014) A synthetic biosocial model of fertility transition: Testing the relative contribution of embodied capital theory, changing cultural norms, and women’s labor force participation. Am J Phys Anthropol 154:322-333. doi: 10.1002/ajpa.22512

Snopkowski K, Sear R (2013) Kin influences on fertility in Thailand: Effects and mechanisms. Evol Hum Behav 34:130-138. doi: 10.1016/j.evolhumbehav.2012.11.004

South SJ, Lloyd KM (1995) Spousal Alternatives and Marital Dissolution. Am Sociol Rev 60:21. doi: $10.2307 / 2096343$

Spitze G, South SJ (1985) Women’s Employment, Time Expenditure, and Divorce. J Fam Issues 6:307-329.

Takyi BK, Gyimah SO (2007) Matrilineal Family Ties and Marital Dissolution in Ghana. J Fam Issues 28:682-705. doi: 10.1177/0192513X070280050401

Teachman JD, Paasch K, Carver K (1996) Social Capital and Dropping Out of School Early. J Marriage Fam 58:773-783. doi: $10.2307 / 353735$

Tzeng JM, Mare RD (1995) Labor Market and Socioeconomic Effects on Marital Stability. Soc Sci Res 24:329-351. United Nations (1992) Demographic Yearbook 1990. New York 
This is an author-produced, peer-reviewed version of this article. The final, definitive version of this document can be found online at Human

Nature, published by Springer. Copyright restrictions may apply. doi: 10.1007/s12110-016-9265-8

Winking J, Gurven M, Kaplan H (2011a) The Impact of Parents and Self-Selection on Child Survival among the Tsimane of Bolivia. Curr Anthropol 52:277-284. doi: 10.1086/659334

Winking J, Gurven M, Kaplan H (2011b) Father death and adult success among the Tsimane: Implications for marriage and divorce. Evol Hum Behav 32:79-89. doi: 10.1016/j.evolhumbehav.2010.08.002

Wood W, Kressel L, Joshi PD, Louie B (2014) Meta-Analysis of Menstrual Cycle Effects on Women’s Mate Preferences. Emot Rev 6:229-249. doi: 10.1177/1754073914523073

Yasui Y (2001) Female multiple mating as a genetic bet-hedging strategy when mate choice criteria are unreliable. Ecol Res 16:605-616. 
This is an author-produced, peer-reviewed version of this article. The final, definitive version of this document can be found online at Human Nature, published by Springer. Copyright restrictions may apply. doi: 10.1007/s12110-016-9265-8

Table 1: Descriptive Statistics

\begin{tabular}{|c|c|c|c|c|c|}
\hline \multirow{9}{*}{ 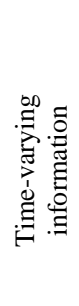 } & Variable & mean & $\mathrm{sd}$ & range & $\mathrm{n}$ \\
\hline & Woman's Income (bolivianos/month, Ln transformed) & 2.82 & 3.24 & $0-10.49$ & 7466 \\
\hline & Husband's Income (bolivianos/month, Ln transformed) & 6.87 & 1.16 & $0-10.82$ & 5446 \\
\hline & Number of Joint Children (truncated at 5) & 2.72 & 1.75 & $0-5$ & 7939 \\
\hline & & $\mathrm{n}$ & $\%$ & Total & \\
\hline & Woman's Employment & & & 7426 & \\
\hline & No income generating activity & 4067 & $54.77 \%$ & & \\
\hline & Works at home & 1016 & $13.68 \%$ & & \\
\hline & Works outside the home & 2343 & $31.55 \%$ & & \\
\hline \multirow{21}{*}{ 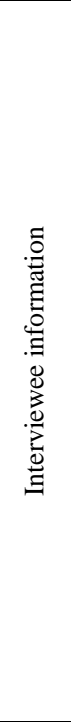 } & & mean & sd & range & $\mathrm{n}$ \\
\hline & Interviewee's Education (in years) & 7.34 & 4.2 & $0-16$ & 388 \\
\hline & & $\mathrm{n}$ & $\%$ & Total & \\
\hline & Lived in San Borja before 15 & & & 174 & \\
\hline & No & 34 & $19.54 \%$ & & \\
\hline & Yes & 140 & $80.46 \%$ & & \\
\hline & Has siblings in San Borja & & & 398 & \\
\hline & No & 99 & $24.87 \%$ & & \\
\hline & Yes & 299 & $75.13 \%$ & & \\
\hline & Birth Cohort & & & 398 & \\
\hline & 1980 - present & 95 & $23.87 \%$ & & \\
\hline & 1970 - 1979 & 116 & $29.15 \%$ & & \\
\hline & $1960-1969$ & 84 & $21.11 \%$ & & \\
\hline & 1950 - 1959 & 60 & $15.08 \%$ & & \\
\hline & Before 1950 & 43 & $10.80 \%$ & & \\
\hline & Church Frequency & & & 394 & \\
\hline & None & 34 & $8.63 \%$ & & \\
\hline & A few times per year & 66 & $16.75 \%$ & & \\
\hline & Monthly & 109 & $27.66 \%$ & & \\
\hline & Weekly & 160 & $40.61 \%$ & & \\
\hline & More than once weekly & 25 & $6.35 \%$ & & \\
\hline \multirow{16}{*}{ 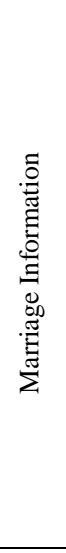 } & & mean & sd & range & $\mathrm{n}$ \\
\hline & Husband's Education (in years) & 8.55 & 4.15 & $0-16$ & 424 \\
\hline & & $\mathrm{n}$ & $\%$ & Total & \\
\hline & Marriages & & & 526 & \\
\hline & Ended in divorce & 171 & $32.51 \%$ & & \\
\hline & Ended in death (of husband) & 20 & $3.80 \%$ & & \\
\hline & Still currently married & 335 & $63.69 \%$ & & \\
\hline & Wedding Type & & & 510 & \\
\hline & No official ceremony & 324 & $63.53 \%$ & & \\
\hline & Civil Union & 103 & $20.20 \%$ & & \\
\hline & Church Marriage & 27 & $5.29 \%$ & & \\
\hline & Both Civil Union and Church Marriage & 56 & $10.98 \%$ & & \\
\hline & Husband helps with bills & & & 505 & \\
\hline & Never/Rarely & 46 & $9.11 \%$ & & \\
\hline & Sometimes & 27 & $5.35 \%$ & & \\
\hline & Always & 432 & $85.54 \%$ & & \\
\hline \multirow{12}{*}{ 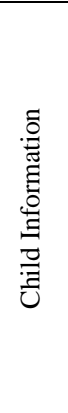 } & & mean & sd & range & $\mathrm{n}$ \\
\hline & Child's age & 29.82 & 9.84 & $10-61$ & 691 \\
\hline & Child's number of siblings & 5.08 & 3.26 & $0-14$ & 691 \\
\hline & & $\mathrm{n}$ & $\%$ & Total & \\
\hline & Child's birth order & & & 691 & \\
\hline & First & 146 & $21.13 \%$ & & \\
\hline & Second & 123 & $17.80 \%$ & & \\
\hline & Third & 108 & $15.63 \%$ & & \\
\hline & Fourth or higher & 314 & $45.44 \%$ & & \\
\hline & Child's sex & & & 691 & \\
\hline & Male & 353 & $51.09 \%$ & & \\
\hline & Female & 338 & $48.91 \%$ & & \\
\hline
\end{tabular}

Note: sd represents standard deviation, $\mathrm{n}$ represents the sample size 
This is an author-produced, peer-reviewed version of this article. The final, definitive version of this document can be found online at Human

Nature, published by Springer. Copyright restrictions may apply. doi: 10.1007/s12110-016-9265-8

Table 2: Random effects discrete-time event history analysis predicting a) progression to divorce, b) progression to divorce for women who remarry and c) progression to divorce for women who remain unmarried

\begin{tabular}{|c|c|c|c|c|c|c|c|c|c|}
\hline & \multicolumn{3}{|c|}{ a) Any divorce } & \multicolumn{3}{|c|}{$\begin{array}{l}\text { b) Divorce with } \\
\text { remarriage }\end{array}$} & \multicolumn{3}{|c|}{$\begin{array}{l}\text { c) Divorce without } \\
\text { remarriage }\end{array}$} \\
\hline & $\begin{array}{l}\text { Log } \\
\text { Odds }\end{array}$ & SE & p-value & $\begin{array}{l}\text { Log } \\
\text { Odds }\end{array}$ & SE & p-value & $\begin{array}{l}\text { Log } \\
\text { Odds }\end{array}$ & SE & p-value \\
\hline Years married & -0.116 & 0.042 & 0.005 & -0.175 & 0.061 & 0.004 & -0.020 & 0.055 & 0.713 \\
\hline $\begin{array}{l}\text { Years married squared } \\
\text { Wife's log income (lagged }\end{array}$ & 0.002 & 0.001 & 0.012 & 0.002 & 0.002 & 0.211 & 0.001 & 0.001 & 0.543 \\
\hline 1 year) & 0.136 & 0.053 & 0.010 & 0.082 & 0.062 & 0.184 & 0.221 & 0.083 & 0.009 \\
\hline Husband's log income & -0.730 & 0.079 & $<0.001$ & -0.810 & 0.079 & $<0.001$ & -0.142 & 0.128 & 0.269 \\
\hline \multicolumn{10}{|c|}{ Employment before divorce (ref = none) } \\
\hline Worked at home & -0.499 & 0.436 & 0.253 & -0.336 & 0.519 & 0.517 & -0.639 & 0.654 & 0.329 \\
\hline Worked outside home & -0.142 & 0.339 & 0.675 & -0.116 & 0.392 & 0.768 & -0.194 & 0.514 & 0.705 \\
\hline Lived in SB before age 15 & -0.154 & 0.376 & 0.686 & -0.010 & 0.497 & 0.984 & -0.184 & 0.389 & 0.637 \\
\hline Have siblings in SB & 0.348 & 0.251 & 0.165 & 0.370 & 0.290 & 0.203 & 0.306 & 0.349 & 0.381 \\
\hline Husband's education & 0.038 & 0.034 & 0.273 & 0.066 & 0.043 & 0.129 & -0.033 & 0.056 & 0.561 \\
\hline Wife's education & 0.095 & 0.033 & 0.004 & 0.048 & 0.039 & 0.226 & 0.090 & 0.047 & 0.053 \\
\hline \multicolumn{10}{|c|}{ Husband helps with bills (ref = Never or rarely) } \\
\hline Sometimes & -1.433 & 0.506 & 0.005 & -1.531 & 0.579 & 0.009 & -1.265 & 0.674 & 0.061 \\
\hline Always & -2.810 & 0.354 & $<0.001$ & -2.891 & 0.372 & $<0.001$ & -1.968 & 0.420 & $<0.001$ \\
\hline \multicolumn{10}{|l|}{ Wedding type (ref = none) } \\
\hline Civil Union & -0.775 & 0.287 & 0.007 & -0.498 & 0.337 & 0.139 & \multirow{3}{*}{\multicolumn{3}{|c|}{$*$}} \\
\hline Church Marriage & -1.469 & 0.616 & 0.018 & -0.648 & 0.603 & 0.283 & & & \\
\hline Both Civil \& Church & -2.097 & 0.506 & $<0.001$ & -1.497 & 0.534 & 0.005 & & & \\
\hline \multicolumn{10}{|c|}{ Frequency of church attendance (ref = none) } \\
\hline A few times per year & -0.763 & 0.436 & 0.080 & -1.049 & 0.502 & 0.037 & -0.235 & 0.591 & 0.691 \\
\hline Monthly & -0.380 & 0.389 & 0.328 & -0.685 & 0.449 & 0.127 & 0.235 & 0.524 & 0.655 \\
\hline Weekly & -0.843 & 0.393 & 0.032 & -1.188 & 0.459 & 0.010 & -0.284 & 0.540 & 0.599 \\
\hline More than once weekly & -0.536 & 0.554 & 0.333 & -0.498 & 0.629 & 0.429 & -0.533 & 0.858 & 0.535 \\
\hline Number of joint children & 0.313 & 0.102 & 0.002 & 0.400 & 0.128 & 0.002 & 0.103 & 0.143 & 0.474 \\
\hline \multicolumn{10}{|c|}{ Birth cohort (ref = 1980 - present) } \\
\hline $1970-1979$ & 0.171 & 0.337 & 0.612 & 1.248 & 0.472 & 0.008 & -1.212 & 0.422 & 0.004 \\
\hline $1960-1969$ & 0.141 & 0.375 & 0.707 & 1.291 & 0.513 & 0.012 & -1.507 & 0.486 & 0.002 \\
\hline 1950-1959 & 0.074 & 0.435 & 0.866 & 1.034 & 0.581 & 0.076 & -1.646 & 0.573 & 0.004 \\
\hline Before 1950 & 0.001 & 0.471 & 0.998 & 0.768 & 0.600 & 0.201 & -1.304 & 0.600 & 0.030 \\
\hline Constant & 2.489 & 0.797 & 0.002 & 2.158 & 0.928 & 0.021 & -2.373 & 1.220 & 0.053 \\
\hline n (unique women) & \multicolumn{3}{|c|}{$7939(398)$} & \multicolumn{3}{|c|}{7939 (398) } & \multicolumn{3}{|c|}{7939 (398) } \\
\hline
\end{tabular}

Bold values represent $p<0.10$.

* Wedding type was not included in the 'divorce without remarriage' model because there were not sufficient people in each category for the model to converge. 
This is an author-produced, peer-reviewed version of this article. The final, definitive version of this document can be found online at Human Nature, published by Springer. Copyright restrictions may apply. doi: 10.1007/s12110-016-9265-8

Table 3: Random effects regression analysis of the effect of the interaction between marital status and a mother's income immediately before divorce on children's educational achievement.

Educational Achievement

Coef. $\quad$ SE $\quad$-value

Income $x$ Remarriage (ref = parent remain married)

Mother did not work before divorce, did not remarry

Mother did not work before divorce, remarried

$\begin{array}{lll}1.454 & 1.549 & 0.348\end{array}$

Mother earned in the bottom 50\% of income before divorce, did not remarry

$-1.142$

0.615

0.063

Mother earned in the bottom $50 \%$ of income before divorce, remarried

$\begin{array}{lll}-1.094 & 1.198 & 0.361\end{array}$

Mother earned in the top 50\% of income before divorce, did not remarry

\section{$-1.618$}

0.668

0.015

0.136

0.936

0.885

Mother earned in the top $50 \%$ of income before divorce, remarried

$-0.812$

Mother's education

0.198

0.588

0.060

0.167

Father's education

0.282

Child's age

$-0.002$

0.058

$\mathbf{0 . 0 0 1}$

Child birth order (ref = First)

2nd

$-0.797$

0.019

$<0.001$

3rd

$\mathbf{- 0 . 6 6 9}$

0.336

0.363

0.018

4th or higher

$-0.214$

0.358

0.066

Child sex = female

0.010

0.220

0.551

Child's number of siblings

$-0.196$

0.079

0.964

Constant

8.801

0.891

0.013

n (unique mothers)

$691(182)$

SE represents standard errors. Bold values represent $\mathrm{p}<0.10$. 
This is an author-produced, peer-reviewed version of this article. The final, definitive version of this document can be found online at Human

Nature, published by Springer. Copyright restrictions may apply. doi: 10.1007/s12110-016-9265-8

Table 4: Random effects regression analysis of the effect of the interaction between marital status and mother's kin availability on children's educational achievement.

Educational Achievement

Coef. SE p-value

Marital status $\mathrm{x}$ Kin (ref = parents married, mother not from SB, mother does not have siblings in SB)

Mother never remarried, mother does not have siblings in SB, mother not from

SB

$\begin{array}{lll}-0.654 & 1.088 & 0.548\end{array}$

Mother never remarried, mother has siblings in SB, mother not from SB

$\begin{array}{lll}-0.891 & 2.179 & 0.684\end{array}$

Mother never remarried, mother has siblings in SB, mother from SB

$0.726 \quad 1.051 \quad 0.490$

Mother remarried, mother does not have siblings in SB, mother not from SB

$\begin{array}{lll}-0.150 & 0.989 & 0.879\end{array}$

Mother remarried, mother does not have siblings in SB, mother from SB

$\begin{array}{lll}1.489 & 1.676 \quad 0.378\end{array}$

Mother remarried, mother has siblings in SB, mother not from SB

$-1.609 \quad 1.121$

0.159

Mother remarried, mother has siblings in SB, mother from SB

Parents married, mother does not have siblings in SB, mother not from SB

$-1.638 \quad 0.480$

$\mathbf{0 . 0 0 1}$

Parents married, mother does not have siblings in SB, mother from SB

$0.180 \quad 0.700$

0.798

Parents married, mother has siblings in SB, mother not from SB

$-0.664 \quad 0.505$

0.189

Mother's education

$0.354 \quad 0.496$

0.476

Father's education

0.192

0.060

0.001

Child's age

$0.278 \quad 0.058$

$<0.001$

Child birth order (reference $=1$ st)

$0.002 \quad 0.019$

0.912

2nd

$\begin{array}{lll}-0.726 & 0.336 & 0.030\end{array}$

3rd

$-0.602$

0.362

0.097

4th or higher

$-0.114 \quad 0.359$

0.752

Child is female

$0.007 \quad 0.222$

0.976

Child's number of siblings

$-0.211$

0.080

0.009

Constant

8.826

0.911

$<0.001$

n (number of unique mothers)

691 (182)

SE represents standard errors. Bold values represent $\mathrm{p}<0.10$. 
This is an author-produced, peer-reviewed version of this article. The final, definitive version of this document can be found online at Human

Nature, published by Springer. Copyright restrictions may apply. doi: 10.1007/s12110-016-9265-8

Table 5: Summary of results

Hypothesis

H1: When males provide little investment, there will be an increased likelihood of divorce
Result

Yes, when investment is measured as men's income or husband helps with household bills, women married to men who invest less are more likely to get 'divorced and remarried'

Women who work outside the home are significantly more likely to 'divorce without remarriage' compared to women who do not work for financial compensation, but only when women's income is not included in the model (suggesting the mechanism by which female employment influences divorce is income).

H3: Women with more income will have a greater likelihood of divorce and remarriage

Women with higher incomes have a greater likelihood of 'divorce without remarriage'

\section{H4: Women with supportive kin have different rates} of marital stability than those without kin

H5: Divorce will lead to reduced educational outcomes for children

H6: Women with greater financial resources are able to buffer their children from the negative effects of divorce and remarriage more than women with fewer financial resources

No effect of kin availability on marital stability Children of women who 'divorce with remarriage' have lower educational outcomes than children of women who 'remain married' or 'divorce without remarriage'

Yes, while children of mothers who 'divorce and remarried' and either did not work or who earned in the bottom $50 \%$ of income have significantly lower educational outcomes compared to children of mothers who remain married, children of mothers who 'divorce and remarried' and earned in the top 50\% of income are not significantly different from children of mothers who remain married

No, children of women who have 'divorced and remarried' and have siblings living in San Borja actually have lower educational outcomes compared to children of women who 'remain married'. Children of women who 'divorce without remarriage' have no significant difference in educational outcomes compared to children of women who 'remain married'. 
This is an author-produced, peer-reviewed version of this article. The final, definitive version of this document can be found online at Human Nature, published by Springer. Copyright restrictions may apply. doi: 10.1007/s12110-016-9265-8

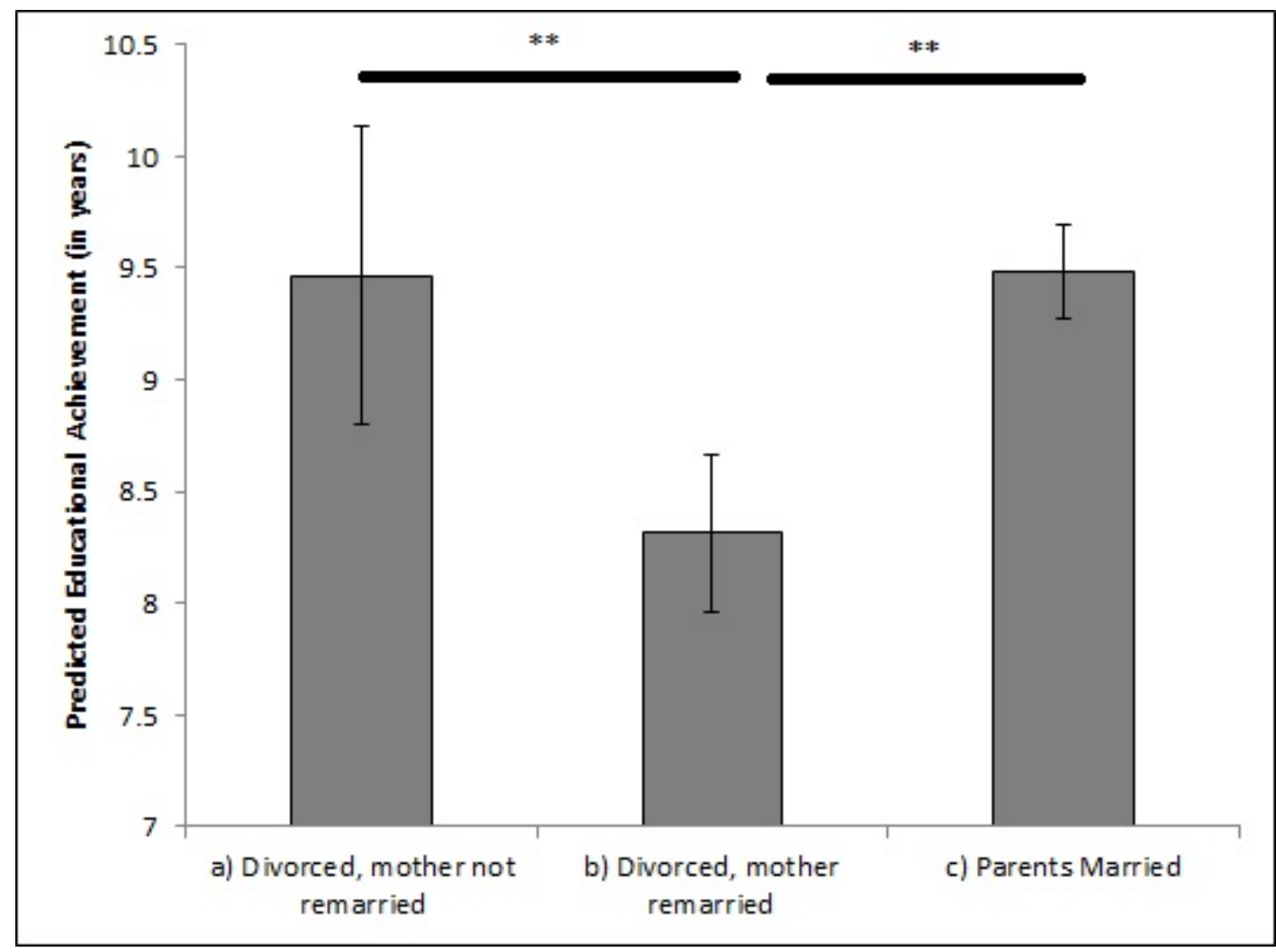

Fig. 1: Predicted educational achievement of children based on parental marital status comparing a) 'divorced but not remarried' mothers, b) 'divorced and remarried' mothers, and c) married parents from a random effects regression analysis which groups children by mother and controls for mother's education, father's education, child's year of birth, birth order, sex, and child's number of siblings. Error bars represent standard errors. ${ }^{* *} \mathrm{p}<0.01$. 
This is an author-produced, peer-reviewed version of this article. The final, definitive version of this document can be found online at Human Nature, published by Springer. Copyright restrictions may apply. doi: 10.1007/s12110-016-9265-8

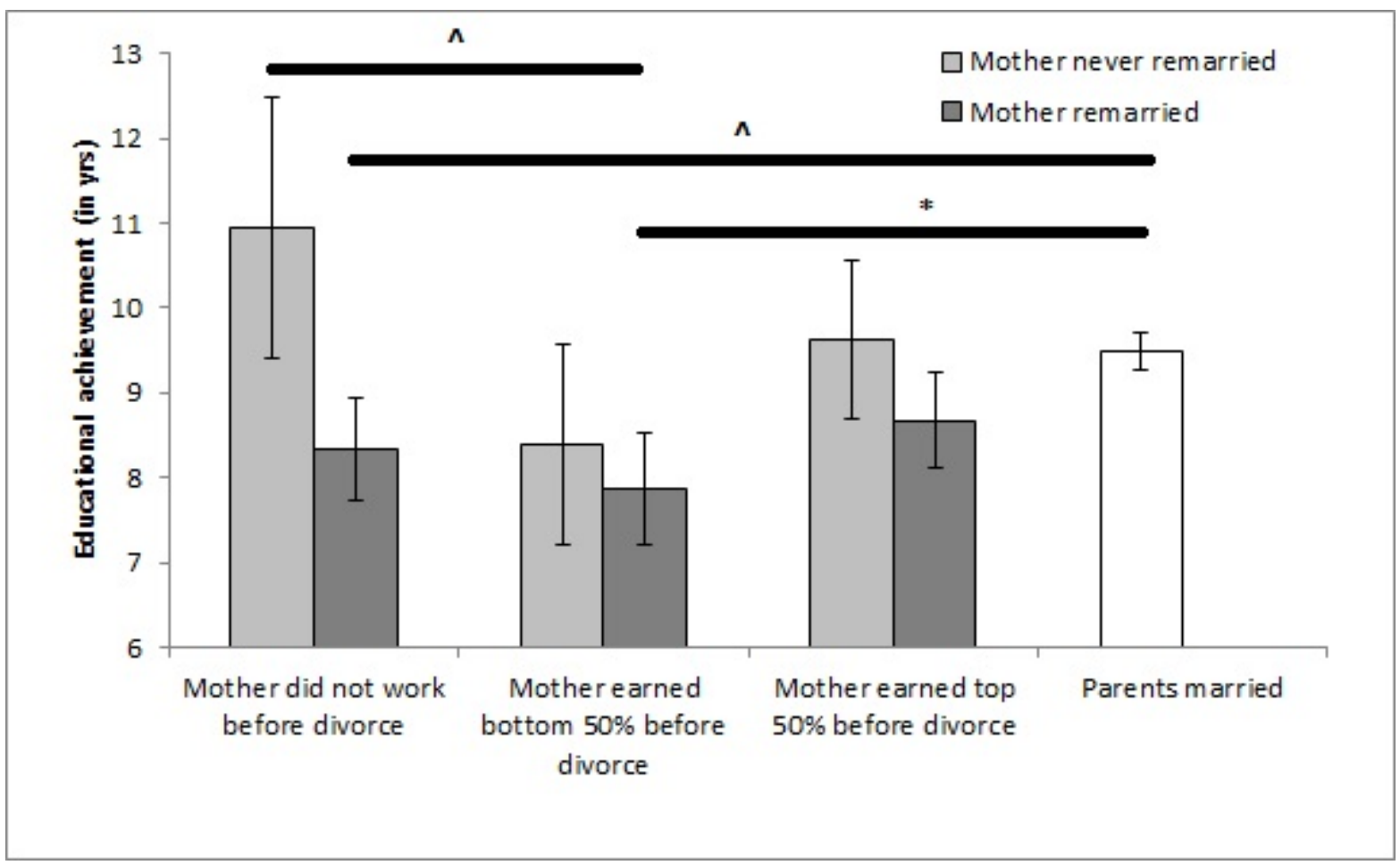

Fig. 2: Predicted educational achievement of children based on mother's income prior to divorce and parental marital status comparing a) married parents, b) 'divorced and remarried' mothers and c) 'divorced but not remarried' mothers from a random effects regression analysis which groups children by mother and controls for mother's education, father's education, child's year of birth, birth order, sex, and child's number of siblings. Error bars represent standard errors. ${ }^{\wedge} \mathrm{p}<0.10,{ }^{*} \mathrm{p}<0.05$. 
This is an author-produced, peer-reviewed version of this article. The final, definitive version of this document can be found online at Human Nature, published by Springer. Copyright restrictions may apply. doi: 10.1007/s12110-016-9265-8

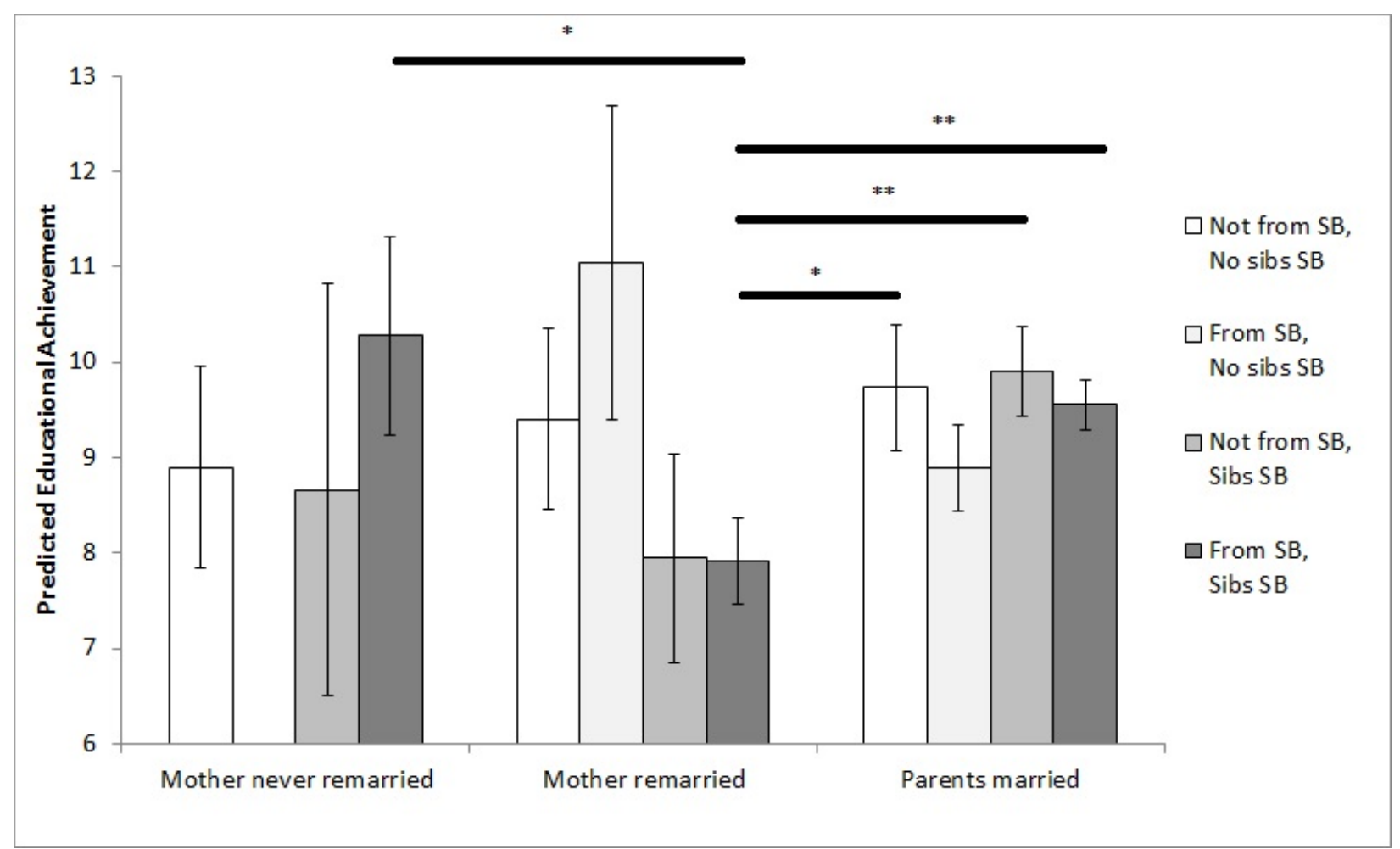

Fig. 3: Predicted educational achievement of children based on the interaction of parental marital status and kin availability. 'From SB' and 'Not from SB' refers to whether the woman began living in San Borja before age 15. 'Sibs SB' and 'No sibs SB' refers to whether the woman has living siblings in San Borja. Predicted probabilities were calculated from a random effects regression analysis, which groups children by mother and controls for mother's education, father's education, child's year of birth, birth order, sex, and child's number of siblings. Error bars represent standard errors. ${ }^{*} \mathrm{p}<0.05,{ }^{* *} \mathrm{p}<0.01$. 